\title{
Nematodes Parasitizing Hops in Florida ${ }^{1}$
}

\author{
Johan Desaeger ${ }^{2}$
}

The rapid growth of Florida's craft beer industry has created new opportunities for Florida growers to introduce and establish commercial hop (Humulus lupulus) operations. This new industry would have the potential to provide new and highly profitable markets for Florida growers. However, many challenges make the establishment of this industry difficult. They include limited knowledge of cultivars (cv.) suited to Florida's climatic conditions and lack of information on potential pests and diseases that will adversely affect this crop in Florida.

\section{Hops: Biology and Production}

Hops belong to the family of Cannabaceae. They are longlived perennials (10-50 years) and have male and female plants. Commercial plants typically are all female and are established by planting rhizomes. Hops plants are climbers and are typically grown on some type of trellis, where the vines wrap themselves around a string positioned above each plant (Figure 1).

Hops are photoperiod sensitive, and they produce best when they receive $15+$ hours of daylight. They will initiate flowering as the day lengths begin to shorten. The best hop-growing regions in the world are usually located between the $45^{\text {th }}$ and $50^{\text {th }}$ parallels north, where the length of daylight appears to be ideal for optimal cone production. In the United States, the vast majority of hops are grown in Washington, Oregon, and Idaho. Whether or not hops can be grown in Florida successfully remains to be seen. Proper cv. selection and the impact of supplemental light during the vegetative phase are currently being investigated. LED lights were installed at the GCREC hop yard to provide supplemental light during the vegetative growth stage (from early March until early May) (Figure 1).
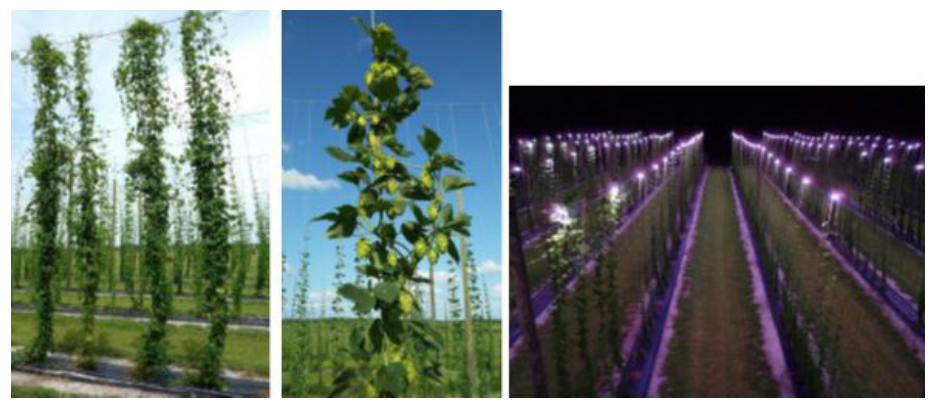

Figure 1. Hop yard at the UF/IFAS Gulf Coast Research and Education Center (GCREC), Wimauma, FL; left: hops growing on trellis; middle: hop cones; right: LED lights at night.

Credits: S. Agehara

The harvestable part of the hops plant that is used in brewing is the cone, which is the flower of the plant (Figure 1). Hop cones are green, pineapple-shaped, and grape-sized nodes, and they add bitterness, flavor, and aroma to the beer. They also have high concentrations of acids that prevent growth of bacteria and that serve as a preservative.

\section{Nematodes: Biology and Importance}

Nematodes are non-segmented roundworms that can be found all over the world in a broad range of environments (marine, freshwater, and terrestrial), as well as parasites of most animals and plants. They all have six life stages,

1. This document is ENY071, one of a series of the Department of Entomology and Nematology, UF/IFAS Extension. Original publication date December 2018. Visit the EDIS website at https://edis.ifas.ufl.edu for the currently supported version of this publication.

2. Johan Desaeger, assistant professor, Department of Entomology and Nematology; UF/IFAS Gulf Coast Research and Education Center, Wimauma, FL 33598. 
including the egg, four juvenile stages, and an adult stage. The nematode reproduces by laying eggs, which hatch to release a juvenile. The nematodes mature through a series of molts as the larvae enlarge and become adult worms.

Adult plant-parasitic nematodes are about 0.04 inches ( 1 $\mathrm{mm})$ long and about 0.001 inches $(25 \mu \mathrm{m})$ in diameter, and they can cause tremendous economic damage in agriculture and horticulture. Their microscopic size and transparent nature make them difficult to detect and to identify. All plant-feeding nematodes have a needle-like, hollow spear mouth part called a stylet that is pushed into the plant cell (Figure 2). The worm forces enzymes through the stylet into the cell, where cell components are digested and then drawn back into the nematode's digestive system through the stylet. Most nematodes occur in soil or in subterranean plant parts, where they feed on living plant tissues, often causing below- and above-ground symptoms such as root galls, lesions, stunting, wilting, or chlorosis.
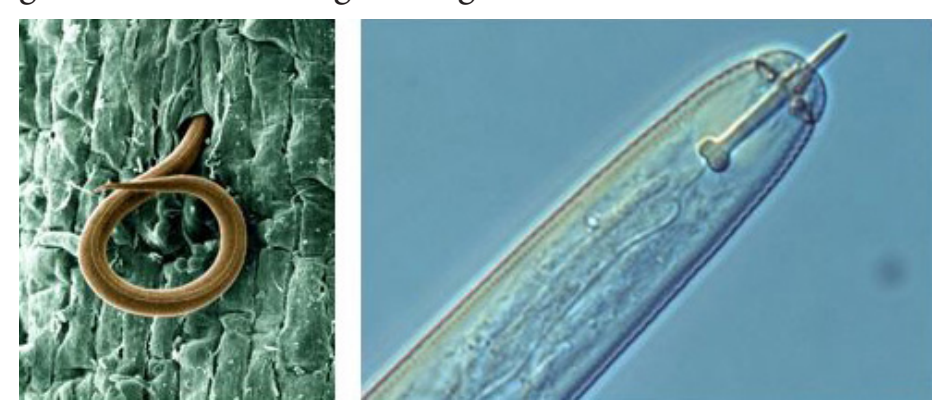

Figure 2. Left: a juvenile root-knot nematode (Meloidogyne incognita) penetrates a tomato root (photo by W. Wergin and R. Sayre, USDAARS); right: head of a plant-parasitic nematode with protruding stylet. Credits: H. Van Megen, Wageningen University

\section{Root-Knot Nematodes}

Meloidogyne spp., or root-knot nematodes, are the most common plant-parasitic nematodes in Florida and the rest of the world. More than 90 species have been described so far, and most of them are tropical to subtropical in nature. They are obligate sedentary endoparasites and parasitize thousands of plant species, including many food crops, vegetables, fruit, and ornamental plants. Several species of root-knot nematodes occur in Florida, mostly M. incognita, M. javanica, and M. arenaria.

The infection process is the same for all Meloidogyne spp. Second-stage juveniles (J2) hatch from eggs in the soil and become the infective stage. J2s penetrate a suitable root, and all subsequent nematode stages are located within the root tissue of the host, where they remain as sedentary endoparasites (Figures 2 and 3). In response to secretions from the J2, the plant forms a giant cell system of trophic cells. With each molt, the nematode becomes more obese, although males, which are rare, become vermiform at the last molt and then emerge into the soil. The obese female swells enormously and produces numerous eggs (typically about 500) in a protective gelatinous matrix.

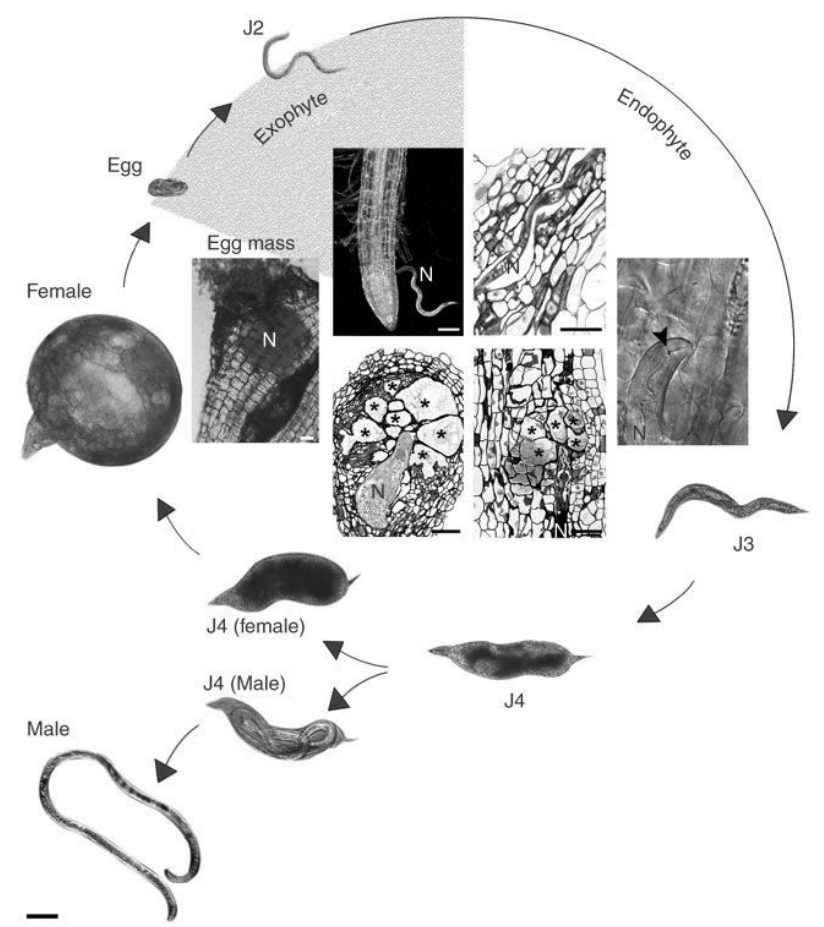

Figure 3. Life cycle of Meloidogyne spp.; infective second-stage juveniles (J2) penetrate the root and migrate between cells to reach the plant vascular cylinder. Each $\mathrm{J} 2$ induces multinucleate and hypertrophied feeding cells (giant cells) that supply nutrients to the nematode $(\mathrm{N})$. The nematode becomes sedentary and goes through three molts (J3, J4, adult). The pear-shaped female produces eggs that are released on the root surface. Embryogenesis within the egg is followed by the first molt, generating second-stage juveniles (J2) (from Abad et al. 2008).

The optimum temperature for invasion and growth of $M$. javanica is in the range of $25-30^{\circ} \mathrm{C}$., and at this temperature the life cycle takes about 3-4 weeks to complete. Typical symptoms of attack include root galls, of which the size and severity will depend on the host and type of root-knot nematode present. In case of M. javanica, root galls are often quite large (Figure 4).

Aboveground nematode damage symptoms include stunted and chlorotic plants and can be confused with damage caused by bacteria, fungi, viruses, nutrient deficiencies, or chemical injuries. Root-knot nematodes may be associated with other pathogens, including bacteria and fungi (such as Fusarium, Rhizoctonia, and Verticillium), which often exacerbate the symptoms.

M. javanica is broadly similar to other members of the genus and normally requires the service of an experienced nematologist to identify to species level with any certainty. 


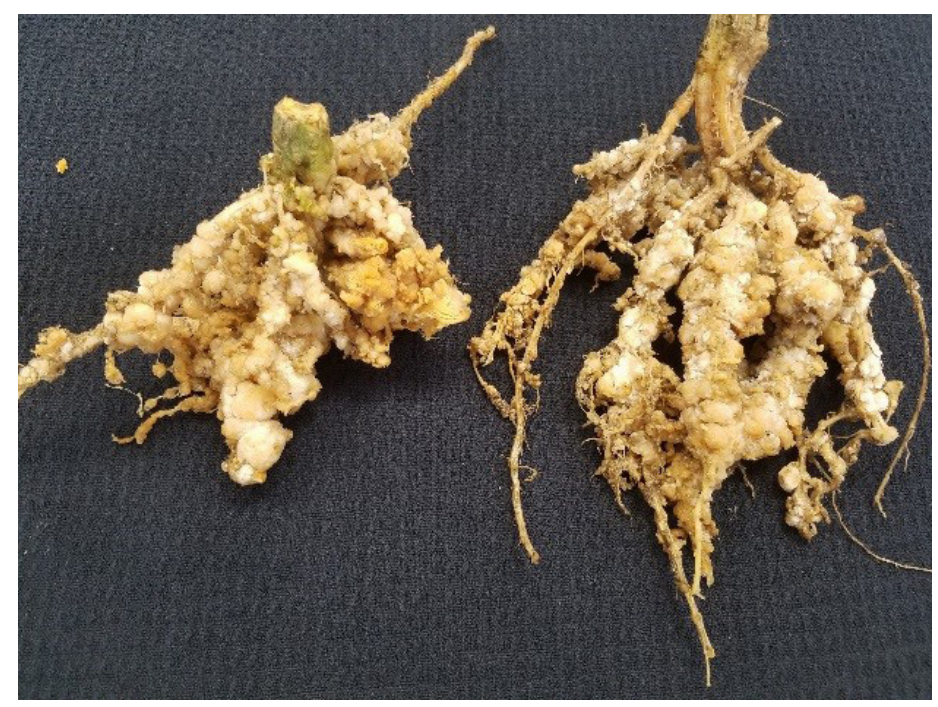

Figure 4. Meloidogyne javanica root gall symptoms on cucumber, UF/ IFAS GCREC, 2017.

Credits: J. Desaeger

\section{Nematodes on Hops}

The nematode most commonly found affecting hops in the traditional hop production areas is the hop cyst nematode (Heterodera humuli). Hop cyst nematodes are sedentary endoparasites (similar to root-knot nematodes), and feed on the young, fibrous roots of hop plants, producing cysts that can survive in soil for years. This nematode may also interact with Verticillium spp. to reduce hop growth and increase the severity of wilt symptoms. Other nematodes that have been reported from hop-growing regions are dagger nematodes (Xiphinema americanum), lesion nematodes (Pratylenchus penetrans), needle nematodes (Longidorus elongatus), spiral nematodes (Helicotylenchus and Rotylenchus spp.), and stem nematodes (Ditylenchus dipsaci) (Warner et al. 2018).

Because hops are new to Florida, no information is available on the nematodes that are associated with hops in the state. After a hop yard was established at the UF/IFAS GCREC in Wimauma, FL, in 2016, several stunted and chlorotic hop plants were observed next to healthy looking plants about four months after establishment (Figure 5).

Roots of stunted plants showed a high number of galls (Figure 5), and soil samples revealed large numbers of plant-parasitic nematodes, especially root-knot nematodes. The root-knot nematode species was identified as Meloidogyne javanica, the Javanese root-knot nematode, a very common species in Florida and a major pest of vegetables in the state (Brito et al, 2018). Except for a report on northern root-knot nematodes (Meloidogyne hapla) on hops from Sacramento County, California (Maggenti 1962), no other reports could be found on root-knot nematodes infecting hops in the United States or elsewhere.

The root galls caused by $M$. javanica on hop roots at the UF/IFAS GCREC were prolific and consisted mostly of discrete, wart-like, brownish knots, giving the roots a bumpy appearance (Figure 5). Hop plants have very extensive and unique root systems consisting of wiry, extensively branched lateral spreading roots (up to $5 \mathrm{~m}$ ), and long, fleshy, irregularly swollen, brittle, and rarely branched vertical roots (up to $9 \mathrm{~m}$ ) (Mikhailyukov and Sigareva 1981; Figure 6). The fleshy swollen vertical roots should not be mistaken for elongated root galls, which are a common symptom of root-knot nematodes on roots of many vegetables (tomato, cucurbits), but not on hops.

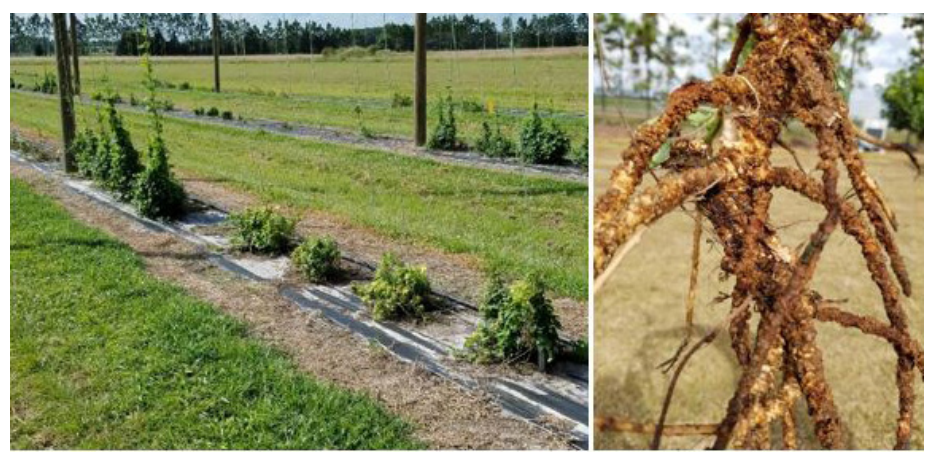

Figure 5. Left: hop yard showing healthy (cv. Cascade) next to stunted and chlorotic plants (cv. Chinook); right: roots of stunted hop plants covered with small brown galls, UF/IFAS GCREC, October 2106.

Credits: J. Desaeger
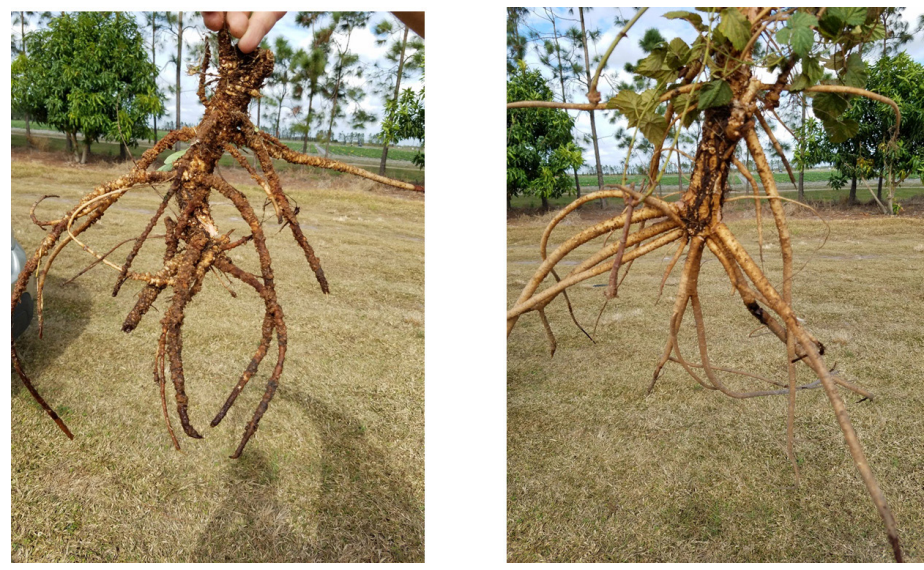

Figure 6. Hops roots at the UF/IFAS GCREC in October 2016. On the left is Cv. Chinook with root galls caused by $M$. javanica; on the right is a healthy specimen of cv. Perle showing no galls. Note also the fleshy, irregularly swollen vertical roots of hops on the right, which is its natural growth habit.

Credits: J. Desaeger

In addition to root-knot, several other plant-parasitic nematodes were found associated with hop roots at the GCREC hop yard, mostly lesion (Pratylenchus spp.) and stubby root nematodes (Trichodoridae), and fewer spiral (Helicotylenchus spp.), ring (Mesocriconema sp.) and sting 
nematodes (Belonolaimus longicaudatus). Recently, stunted hop plants were also noted at a UF/IFAS hops yard in Orange County, FL (K. Greer). The affected plants were again associated with galled and stunted roots and showed large numbers of root-knot, spiral, and stunt (Tylenchorhynchus spp.) nematodes.

\section{Nematode Management on Hops}

There are no good management practices for heavy infestations of nematodes on hops. The key is to implement management strategies preventatively. Planting hops on nematode-free land, applying a fumigant before the establishment of a new hop yard, and using nematode-free plant material are all good preventative measures to at least ensure proper establishment of newly planted hops. Hot water treatment has been successfully used to cleanse hop planting material. Soaking the rhizomes in hot water $\left(122^{\circ} \mathrm{F}\right.$ for 10 minutes or $125^{\circ} \mathrm{F}$ for 5 minutes) killed nematodes and did not injure the rhizomes (Maggenti 1962).

Cultivar screening and selection of resistant and/or tolerant varieties may offer the best opportunity to manage rootknot nematodes in Florida hops.

The different hops cultivars that were initially planted at the UF/IFAS GCREC showed significant differences in their root-knot nematode host status. Both field and greenhouse assessments at the UF/IFAS GCREC have shown that cv.s Chinook, Fuggle, Comet, Cashmere, and Zeus are the most susceptible to root-knot damage, and cv.s Magnum, Perle, and Cascade the least susceptible. Cultivars Nugget and Centennial were somewhere in between. Nematode management will be important if hops is to become an economically viable crop in Florida, and the right selection of cultivars will be essential to achieve this. Hops cultivar screening for root-knot nematode host status will continue at the UF/IFAS GCREC in the next years, and we will update this publication as new results come in.

\section{Acknowledgements}

The author wishes to acknowledge Dr. Z. Deng, Dr. S. Agehara, and S. Bollin for initiating and managing the hops yard at the UF/IFAS GCREC, and FDACS and the Florida microbrewery industry for their support.

\section{References}

Abad, P., J. Gouzy, and P. Wincker. 2008. "Genome sequence of the metazoan plant-parasitic nematode Meloidogyne incognita." Nature Biotechnology 26: 909-915.
Brito, J. A., Subbotin, S. A., Desaeger, J., Achinelly, F. and Qiu, S. 2018. Meloidogyne javanica infecting hop (Humulus lupulus) in Florida, USA: a study case. Society of Nematologists Annual Meeting, July 22-26, 2018, Albuquerque, NM

Greer, K. UF/IFAS Extension agent. Personal communication.

Maggenti, A. R. 1962. "Hot water treatment of hop rhizomes for nematode control." California Agriculture 16: $11-12$.

Mikhailyukov, U. S., and D. D. Sigareva. 1981. "The nematode fauna of hops in the Zhitomir region." Vestnik Zoologii 2: 41-46.

Warner, F., G. Bird, F. Hay, R. Sirrine, and D. Gent. 2018. Nematodes. https://www.usahops.org/cabinet/data/5.pdf Accessed 6/4/2018 